\title{
Forgiveness among mothers of female adolescents who experienced unwanted pregnancy
}

\author{
Mohammad Adi Ganjar Priadi ${ }^{1}$, Gurmichele ${ }^{2}$ \\ ${ }^{1,2}$ Faculty of Psychology, Atma Jaya Catholic University of Indonesia, Indonesia \\ ${ }^{1}$ mohammad.adi@atmajaya.ac.id, ${ }^{2}$ official.michelle24@gmail.com
}

\section{ARTICLE INFO}

Article history

Received 25 November 2018

Revised 15 August 2019

Accepted 01 September 2019

Keywords

forgiveness

maternal forgiveness

unwanted pregnancy

\begin{abstract}
Unwanted pregnancy is an issue that affects, not only the individual who got pregnant, but also their mothers. Such a traumatic experience may cause psychological distress in these mothers, affecting their overall psychological well-being. This study aimed to explore the process of maternal forgiveness experienced by mothers in dealing with their children who had unwanted pregnancy. Qualitative method was applied in this research. Participants were selected by purposive sampling technique. Three mothers of young women who experienced unwanted pregnancy participated in this research. The results highlight the forgiveness process experienced by three participants. Forgiveness process start with negative emotion of the mothers, followed by giving empathy to her daughter as part of the forgiveness process. Self contemplation plays a crucial role on mothers' transition from feeling negative emotions to giving emphaty to their daughters.
\end{abstract}

\section{Introduction}

Unwanted pregnancy is a phenomenon that can be found among Indonesian female adolescents. Unwanted pregnancy occurs when female adolescents unintentionally became pregnant (Widyastuti, 2009) as a result of either intentional or unintentional sexual behavior or sexual intercourse. Most unwanted pregnancies are considered as a stressful life event for most women regardless of their age (Coleman, 2006). Data revealed that more than 32,000 Indonesian women experienced unwanted pregnancies between 2010 to 2014; an unusually high rate compared to other ASEAN countries (The Jakarta Post, 2015), and also the highest in South-East Asia region (Anand, Unisa, \& Singh, 2017).

The number of young people aged 10-24 who experience unwanted pregnancies has reached 63,4 million, stressing the need to put adolescent pregnancy as a crucial challenge in Indonesia that needs to be addressed (Utomo \& Utomo, 2013). The Indonesian Planned Parenthood Association (PKBI) in Central Java revealed that, on average, there are roughly 8-10 adolescents each month who consulted about their unwanted pregnancy problem (Utomo \& Utomo, 2013). The high rate of unwanted pregnancies needs to be examined indepth, considering that adolescents are more prone to experiencing psychological problems because of their issues.

Adolescence can be categorized until age 24; the modern border for adolescence age is 14-21 years (Sarwono, 2001). Nowadays, adolescence also experiences changes in values and liberals, causing them to be easily exposed to premarital sexual behavior. Adolescents are also at a high risk of experiencing unwanted pregnancies. The leading causes of unwanted pregnancy among adolescents are the lack of sexual and reproductive health 
education and a weak self-efficacy of teenage girls to reject premarital sex demanded by their partner (Mayun, Ani, \& Suariyani, 2017). In short, family members still label unwanted pregnancy as a shameful experience. Therefore female adolescents with unwanted pregnancy feel disappointed and fearful over facing their pregnancy (Bird \& Melville, 1994). For instance, people have the potential to ridicule, ostracize, and even expel women who were found to have unwanted pregnancy (Romauli \& Vindari, 2011).

Female adolescents who experienced unwanted pregnancy have very few choices (Rosmalinda, 2003), one of which is abortion (Soetjiningsih, 2010). This because there are negative consequences for adolescents who experienced an unwanted pregnancy, such as disruption of interpersonal relationships between family members. Unwanted pregnancy also greatly affects parents, particularly mothers. Unwanted pregnancy could also jeopardize them as parents. Parents of daughter who committed unplanned pregnancy tend to feel hurt, angry, and disappointed (Farber, 1991). These statement confirmed that parents from daughter who had unwanted pregnancy will experience social judgment from society (Sridawruang, Crozier, \& Pfeil, 2010). Parents also feels guilty for feeling like they failed in raising their daughter (Soetjiningsih, 2010).

In general, parents may respond with negative emotions when they believe their children are unsuccessful. However, mothers and fathers may respond with different negative emotions (Cichy, Lefkowitz, Davis, \& Fingerman, 2013). Father often experience anger and will attempt to try to solve this problem directly. On the other hand, mother could experience more difficulty in giving forgiveness. Compared to fathers, mothers have massive susceptibility for experiencing psychological problem (Toussaint, Worthington, \& Williams, 2015). This is because women, as compared to men, tend to react differently to conflicts related to psychological problems. Men expresses more externalized emotions (i.e., anger related with justice and morality) while women may be more drawn to warmth based virtues which led to sadness and disappointment (Miller, Everett, Worthington \& McDaniel, 2008). Therefore, differences may be found between men and women in the way that they forgive (Ghaemmaghami, Allemand, \& Martin, 2011).

Furthermore, the closer the relationship in the family such as mother and child, the greater chance for disappointment. Indirectly, mother usually has a strong emotional bond with her daughter. This is due to the way society defines mothers as a gentle and nurturing figure for their children. Mother also plays as an important figure particularly in raising children. Therefore, mother always try to nurture their children in every situation despite feeling disappointed by them (Nurrachman \& Bachtiar, 2011). In other words, women tend to be more empathic while they experience and process complex unpleasant events. Women, especially mothers, have their own uniqueness in relating to forgiveness.

Research on forgiveness is rising because of its benefit. Forgiveness motivates people not to take revenge, lessen hatred, and reconcile with the one who hurt their feelings (Fincham, Hall, \& Beach, 2006). Instead of growing hatefulness, individuals can forgive by showing care, generosity, and even love to those who hurt them (Enright, Freedman, \& Rique, 1998). Therefore, forgiveness is associated with improved mental health and wellbeing (Toussaint \& Jorgensen, 2008). Volf states that forgiveness is more than just overcoming anger and resentment (Inazu, 2009). The higher the forgiveness, the less someone would be vulnerability to physical and psychological disorders (Younger, Piferi, Jobe, \& Lawler, 2004). Forgiveness has a crucial role in attaining health and overall development, as it is an essential healing mechanism which aids individuals in coping from negative emotion or unpleasant experience. It also supports to reenergize hearts and rebuilds life (Pareek \& Mathur, 2013). 
Worthington, Jr (2006) expressed forgiveness as a continuum process of giving mercy to people who have once hurt an individual. People will experience five stages of forgiveness, namely, Recall the hurt, Empathize with the one who hurt you, Give an altruistic gift of forgiveness, Commit to the forgiveness you experienced, and Hold on to forgiveness (REACH) (Worthington Jr, 2006). The first stage is recalling the hurt in which people try to remember the hurt and pain that they first experienced. The second stage is empathizing with the person who hurt them, which is when someone tries to understand a situation from the offender's perspective. The third stage is giving an altruistic gift of forgiveness; when people try to remind themselves that they have once hurt other people too, increasing their willingness to forgive. The fourth stage is committing to the forgiveness that has been given by not remembering the experience again. Lastly, the fifth stage is to hold on to forgiveness by retaining and remembering the benefits of their forgiveness. In addition, the last stage in the process usually requires a degree of de-emphasizing the betrayal and intense anger that was previously experienced (Murray, 2002).

Forgiveness plays a pivotal role because it is related to interpersonal problems. Many studies about forgiveness are limited to family problems between mothers and children. This study aimed to provide new knowledge about the process of how Indonesian mothers forgive their daughter who became pregnant outside of marriage.

\section{Method}

This study used a qualitative research method for data collection, more specifically using interviews. Case study approach was applied in this study. Participants must be mothers of female adolescents (aged 12-21 years) who have experienced unwanted pregnancy. In total, there were three participants in this study. Open standardized guidelines of interview was used in this study as it has detailed interview guidelines, set of questions and elaboration in sentence (Poerwandari, 2009). The interview guide used in this study explored the description of events and the forgiveness process of participants. The event description category aims to understand the process of the participants knowing that their teenage daughters experience unwanted pregnancy. The interview explored about the motherdaughter relationship, chronology of discovering the news about the unwanted pregnancy, as well as the thoughts and emotions that participants experienced at that moment.

\section{Data collection}

Purposive sampling - a deliberate sample selection technique to be studied or understood according to the main phenomenon (Creswell, 2012) - was used in determining participants. Before recruiting process, information about this research was disseminated. Prospective participants who were willing to take part in the study and met the inclusion criteria were contacted and scheduled for interview.

\section{Data analysis}

Five-phased cycles were applied in analyzing the data (Yin, 2009). Data analysis began by compiling (combining data), disassembling (giving code and sharing), reassembling (categorizing codes into similar themes), interpreting (understanding participants' explanations and exploring topics), and drawing final conclusion after the data has been analyzed in its entirety.

\section{Ethical consideration}

Prior to data collection, participants were asked to sign an informed consent. The informed consent also depicted information about the use of pseudonyms in reporting the research 
result and possible psychological risk of participating in the study (e.g., recalling unpleasant experience and emotion).

\section{Results}

\section{Participant $R$}

$\mathrm{R}$ is a 49-year-old woman from Punjabi (India) and lives in the city of $\mathrm{J}$, Indonesia. $\mathrm{R}$ is the mother of $\mathrm{K}$; her only daughter. $\mathrm{R}$ and $\mathrm{K}$ 's relationship can be described as harmonious. $\mathrm{R}$ always takes care of $\mathrm{K}$ since childhood. When $\mathrm{K}$ was 14 years old, K's father died. Since that time, $\mathrm{R}$ acted as a single mother in raising $\mathrm{K}$.

$\mathrm{K}$ grew into a child that made her parents proud. According to $\mathrm{R}, \mathrm{K}$ has always been a submissive and accomplished child, especially in the field of religion. When $\mathrm{K}$ was 16 years old, she expressed her intention to go to India to explore her knowledge about her religion Sikh. R allowed K to go to India with the hope that she can reunite with K once more after $\mathrm{K}$ returns from the country. Two years later, when $\mathrm{K}$ was 18 years old, she returned to Indonesia. $\mathrm{K}$ talked with $\mathrm{R}$ about her desire to support the family's financial by registering to work as a flight attendant at an airline company. $\mathrm{K}$ finally got a position and was scheduled to fly every two weeks. According to R, during her duties and work, she always greeted and monitored K's presence through telecommunications media. $\mathrm{R}$ also said that $\mathrm{K}$ was 18 years old so it was time for her to be independent and responsible of herself. For this reason, $\mathrm{R}$ became less aware of the development of K's love life. Even so, she knew that her daughter was in a relationship with someone with a different religion.

One day, $\mathrm{R}$ received a call from $\mathrm{K}$ who requested to meet at the $\mathrm{D}$ city airport immediately. $\mathrm{K}$ told $\mathrm{R}$ that she was going to get married in a few days. $\mathrm{R}$ was perplexed but did not put the slightest bit of suspicion about what happened at that time. $\mathrm{R}$ then followed her daughter's request to meet at the airport in the city of $\mathrm{D}$. When they met at the airport, $\mathrm{K}$ informed her that she was already pregnant from her relationship with her lover. For that reason, $\mathrm{K}$ planned to get married as soon as possible and begged $\mathrm{R}$ to attend. At the time, $\mathrm{R}$ admitted that she was furious. She slapped and beat $\mathrm{K}$ in front of many people. $\mathrm{R}$ felt angry because $\mathrm{K}$ has disappointed her by misusing the trust that has been given. $\mathrm{R}$ did not think that her daughter could do something that would humiliate $\mathrm{R}$ and her reputation.

"I slapped her; I beat her up right there. I didn't care about other people at the airport. I kicked her. I felt hurt, I didn't know what to say" (spoke with tears).

After R slapped and beat a silent K, K apologized in the middle of R's anger. R finally decided to return to $\mathrm{J}$ city and left $\mathrm{K}$ at the airport because $\mathrm{R}$ felt that she could not forgive $\mathrm{K}$. $\mathrm{R}$ had thought about not contacting $\mathrm{K}$ back. In addition to feeling angry, disappointed, and hurt, $\mathrm{R}$ also felt tremendous concern with the response of her extended family. $\mathrm{R}$ said that she often felt guilty and experienced emotional changes without cause. $\mathrm{R}$ often cried and withdrew from the environment, loss appetite, and lack of self-care. During this time, she felt a sense of discomfort due to becoming the talk in her extended family.

"I had thought about things, like surely the big family would talk about it, in fact, some relatives came to my house just to be angry, some relatives found out through text on WhatsApp, some are annoying in groups".

As time went on, $\mathrm{R}$ attempted to empathize with $\mathrm{K}$ by imagining to be in her position. She questioned what she would do in her daughter's place. She imagined how difficult it must be to go through this problem without the support from her closest people. Therefore, $\mathrm{R}$ began to try to take a stand by empathizing with the events experienced by her daughter. "I thought, what if this happened to me? $K$ and I are no different. If my position was traded with $K$, I would have gone crazy. It must be such a sad experience for K. She must be feeling so depressed and lonely". 
$\mathrm{R}$ received another apology from $\mathrm{K}$ a few months after the airport incidence. $\mathrm{R}$ remembered that there was a time when $\mathrm{K}$ had visited with her newborn baby to once again apologize and beg for R's forgiveness. They then cried and held each other. R felt she had made a big mistake because she could not take care of her daughter. $\mathrm{R}$ blamed herself for the unwanted pregnancy that befell $\mathrm{K}$.

R's psychological condition eventually improved, $\mathrm{R}$ began to feel relieved and determined to maintain the forgiveness given to her daughter. She also received much support from her partner. $\mathrm{R}$ has a lover - after her previous marriage - who always encouraged her to forgive $\mathrm{K}$.

In the end, $\mathrm{R}$ felt more relaxed, as the benefits of forgiveness. She also tried to spend time with positive things and began to be able to visit her grandchildren who live outside the city. In terms of physical health, R's appetite has returned; she was able to take care of herself again. $\mathrm{R}$ has also been able to re-socialize with her extended family because they gradually stopped gossiping about her daughter.

\section{Participant $T$}

$\mathrm{T}$ is a 46-year-old Sundanese woman and the mother of $\mathrm{M}$. $\mathrm{T}$ and $\mathrm{M}$ has a fairly comfortable relationship with each other. They often spend time to do positive activities together. $\mathrm{T}$ is a fairly modern mother figure and has a lenient style in raising her daughter. T caught $M$ looking pale and lethargic. At first, she thought that $\mathrm{M}$ merely spent too much time studying and got sick. A few days later, T saw $\mathrm{M}$ vomiting without any cause. The condition continued until $\mathrm{M}$ finally apologized and told $\mathrm{T}$ that she was pregnant.

The psychological condition of the family members at home at that time started to heat up. T's husband was furious and came to the man who had impregnated his daughter but the man has left without a trace. T was worried of the fact that $\mathrm{M}$ will have to undergo the national high school exam in three months. T then cried and stopped having coversation with $\mathrm{M}$ for a while. $\mathrm{T}$ could not bring herself to imagine the life that her daughter must live; raising a child without a husband.

As a parent, T felt broken, angry, and sad. She was not able to speak out her thoughts. She wanted to tell her daughter that she was willing to fully accompany her in going through this experience, but she was reluctant to do so because she had not fully accepted the situation. At that time, she tried to calm down and pray. She was greatly concerned that her daughter will be the subject of rumors from neighbors. $T$ felt that she needed the support of her sister, who, she considered to be the closest person to her besides her husband. She asked her sister to stay with her for a while.

"One time, I was going to take some water and passed by her room. I saw her sleeping like that. Her face was really tired. I just remembered, just like this sudden pregnancy. As a mother, I was sad to see my child like that. I wanted to caress, hug, and tell her not to worry because I'm there for her."

After several months passed, $\mathrm{T}$ experienced negative emotion when she began to feel guilty for having no conversation with $\mathrm{M}$. T finally came to $\mathrm{M}$ and said that she had forgiven the incident that happened. T imagined that, if she was in M's position, she probably would not be able to think clearly and would abort her baby. After trying to empathize, the desire to forgive was getting stronger because she also wanted to correct her mistakes as a parent who, according to her, failed to educate $\mathrm{M}$. T also thought she will regret not talking to $\mathrm{M}$. "after feeling and imagining being in her position, I thought in the room. There is a great desire in my heart to forgive $M$, I wanted to correct my mistakes as a mother. I also felt that I'm not a perfect mother, so I wanted to make amends by forgiving M." 
Later, $\mathrm{T}$ opened her heart to forgive and sincerely said those words to $\mathrm{M}$. $\mathrm{T}$ also apologized to $\mathrm{M}$ and confessed her mistakes of not talking to $\mathrm{M}$. Furthermore, $\mathrm{T}$ also persuaded her husband to forgive $\mathrm{M}$. T promised to focus in accompanying $\mathrm{M}$ throughout her pregnancy until childbirth. She felt grateful for being able to get through with it. After she forgave M, she felt like she was able to concentrate more on her daily activities. In addition, her anxieties over getting rumors from her neighbours gradually diminished.

"I just told my husband that I forgive M. I will look after M until my grandchild is born. Then I persuaded my husband to forgive M too"

\section{Participant $S$}

$\mathrm{S}$ is a 47-year-old Minahasan woman and the mother of $\mathrm{P}$, a teenage girl. $\mathrm{S}$ and $\mathrm{P}$ have a typical mother-daughter relationship. The only difference, compared to previous respondents, is that $\mathrm{S}$ and $\mathrm{P}$ live in the same house but spends less time together. $\mathrm{S}$ does not know enough about P's circle of friends, but $\mathrm{S}$ often asks and communicates intensely towards $\mathrm{P}$ especially about her relationships.

$\mathrm{P}$ is an individual who enjoys traveling and spending time with her friends. $\mathrm{P}$ already has a boyfriend and he has been introduced to $\mathrm{S}$ and her father. $\mathrm{P}$ have traveled abroad with her boyfriend quite often in the past. At that time, $\mathrm{S}$ trusted $\mathrm{P}$ fully and did not want to evoke rigid rules and education to $\mathrm{P}$. $\mathrm{S}$ did not want $\mathrm{P}$ to be a child who defies her behind her back. $\mathrm{S}$ was trying to avoid repeating the same pattern that her parents once gave her. For that reason, $\mathrm{S}$ and her husband gave $\mathrm{P}$ full freedom because they considered her as an adult; capable to taking care of herself.

$\mathrm{S}$ identified a change in P's pale and weak physical condition. At that time, $\mathrm{P}$ had just returned home from a vacation with her boyfriend. S did not attribute those physical changes in $\mathrm{P}$ as an indication of her pregnancy. Surprisingly, P's boyfriend suddenly came to the house and said that he would marry $\mathrm{P}$ immediately. P's boyfriend admitted that he impregnated $\mathrm{P}$ and would be responsible by marrying her. $\mathrm{S}$ felt sad and broken at the time, she remembered slapping P's boyfriend and crying as her initial reaction. She felt sad and disappointed because the trust she had given so far was wasted by $\mathrm{P}$ and her boyfriend.

"I was very angry. I lost my words. I trusted $P$ at that time to be with her boyfriend, but why did he impregnate P...that was my thought at the time. P disappointed me as her parents, and she misused the trust that I gave her"

Even though S felt angry, sad, and disappointed because of her daughter's unwanted pregnancy, she continued to try and find a solution for the problem. S slowly tried to invite her husband and child to discuss the marriage plan. Marriage was held to maintain the reputation of the family. S remembered that she had no conversation with $\mathrm{P}$ since the early stages of the event until the wedding. During the wedding, $\mathrm{S}$ often went to be alone to pray and beg God's forgiveness because she felt she has failed as a parent. Even so, S was relieved when $\mathrm{P}$ and her boyfriend finally got married.

After the wedding took place, S kept thinking over the events that happened to her daughter. She tried to position herself in P's condition. She admitted that she might have chosen to do an abortion if she was in P's position. However, she was relieved that $\mathrm{P}$ and her boyfriend had the courage to confess about this incident. S felt that, at least, $\mathrm{P}$ and her boyfriend were both willing to be responsible over what they have done. S's attitude to P and her boyfriend finally softened. S was able to hug P once after the wedding took place and tried to forgive her. S also told P's husband that $\mathrm{P}$ is now fully his responsibility.

$\mathrm{P}$ and her husband live separately from $\mathrm{S}$ after the marriage but they would often visit $\mathrm{S}$ 's house. At that time, $\mathrm{P}$ asked whether $\mathrm{S}$ was still angry. $\mathrm{S}$ became contemplative and again felt guilty for being a negligent parent in paying attention to her daughter. However, she 
decided to forgive and accept the reality when she saw P's difficulty during the pregnancy period.

"She had asked me, whether I was still angry with her or not, I wasn't angry with her anymore, I'm not an angry person. I'm wasn't angry, I felt guilty. What kind of a mother was I? I was always busy so I didn't pay enough attention to my daughter"

$\mathrm{S}$ then prayed more often with her husband. She frequently told her husband at night before going to bed that she had forgiven the incident. She also promised to still love her child even if she made a mistake. S felt more positive and vibrant in her life. She tried to keep forgiving what she had done with positive behavior by accompanying $\mathrm{P}$. S finally reduced her work schedule as an entrepreneur to accompany her grandchild's birth. After the birth of her grandchild, $\mathrm{S}$ became more excited and was able to live her days in a much more relaxed way. She enjoys playing with her first grandchild. Now, P has had a second child and S's life has gradually recovered. She no longer blames herself but tried to improve the quality of her relationship with $\mathrm{P}$ and enjoys her role as a grandmother.

"At that time, I prayed to God, I gave thanks because I was able to forgive my daughter. It was enough to make me relieved (nodded). After I prayed, as soon as I saw my husband enter the room, I began to relax with him. "Pak, I have forgiven P", I cannot wait to see my grandchildren. For once I am excited!".

The results found that the three participants had their own characteristics in the process of forgiveness. In participant $\mathrm{R}$, the process that appeared first was guilt and disappointment over the daughter's unwanted pregnancy event. Concern related to becoming a subject to rumors also emerged. There was a strong and profound feelings of feeling betrayed that $\mathrm{R}$ felt because $\mathrm{K}$ misused the freedom that $\mathrm{R}$ has given. In participant $\mathrm{T}$, the process that consistently appeared are feelings of sadness and confusion in accompanying her daughter who is pregnant out of marriage. T also expressed concern that the problems experienced by her daughter would be gossiped by neighbors. An answer that is also strong and consistent at the end of the interview is the willingness of $\mathrm{T}$, as a mother, to accompany her daughter even in a shocked psychological condition.

\section{Discussion}

In line with the research objectives, the results of this study provide data on the forgiveness process of the participants. First mother $(\mathrm{R})$ experienced negative emotions when knowing that her daughter $(\mathrm{K})$ was pregnant. Based on Worthington Jr's theory, at this stage, $\mathrm{R}$ experienced the stage of "recall the hurt", when she felt a deep hurt and anger because she felt the trust she had given was wasted. Later, during the "empathize with the one who hurt you" stage, $\mathrm{R}$ admitted that she would not know what to do had the same problem happen to her. That realization brought $\mathrm{R}$ to gradually showed mercy to $\mathrm{K}$. At the "give an altruistic gift of forgiveness" stage, $\mathrm{R}$ said that $\mathrm{K}$ once kneeled to apologized. The "commit to the forgiveness you experienced" stage was marked by R's effort to be consistent in forgiving $\mathrm{K}$. In the end, at the "hold on to forgiveness" stage, R felt more relaxed. She also tried to spend time doing positive activities and began to visit her grandchild, who lives outside the city.

Second mother $(\mathrm{T})$ experienced recall the hurt when she remembered the moment her daughter (M) broke the news about the unwanted pregnancy. She felt devastated, angry, and sad as a parent. At that time, she tried to calm down and pray. She was greatly concerned about her daughter who might become the subject of their neighbor's gossip. Later, $\mathrm{T}$ underwent an empathize stage when she began to feel guilty for not talking to her daughter. T also imagined what she would do if she was in M's position and admitted that she probably would not be able to think clearly and do an abortion. At the "give an altruistic gift of 
forgiveness" stage, after trying to empathize, she had a stronger desire to forgive because she also wanted to correct her mistake of failing to educate M. In the next stage, "commit to the forgiveness you experienced", T opened her heart to sincerely express her forgiveness to M. After that phase, she felt grateful that she was able to get through with it. In the next stage, "hold on to forgiveness", she felt that she was able to concentrate more on her daily activities after that forgiveness stage.

The third participant (S), felt angry, sad, and disappointed of her daughter (P). At this stage - based on Worthington Jr's theory - S experienced the "recall the hurt" when memories of unpleasant experiences are still strongly remembered within her. After the daughter's marriage, in line with the "empathize with the one who hurt you" stage, S was able to hug $\mathrm{P}$ and tried to forgive the events that occurred. Although $\mathrm{S}$ was disappointed with this event, she was grateful that $\mathrm{P}$ and her husband remained together. In this condition, $\mathrm{S}$ experienced the "give an altruistic gift of forgiveness" stage when she felt worthy of giving forgiveness to her daughter because she also felt guilty. S often told her husband that she had forgiven and promised to love her daughter even after $\mathrm{P}$ made these mistakes. $\mathrm{S}$ experienced the "commit to the forgiveness you experienced" phase when she decided to try to forgive her child. S tried to behave positively by accompanying P. After the birth of her grandchild, $\mathrm{S}$ became more excited and relaxed in living her daily life. Based on Worthington Jr's theory, this condition can be categorized as the "hold on to forgiveness" stage.

The present findings highlight mothers' unique ability to maintain a relationship with their child and accept their grandchildren. The participants considered themselves as parents who failed to raise their children and tried to correct their mistakes by accompanying their daughters until they were willing to forgive. The three participants also stated that they were basically human beings who had made mistakes with other people. This conclusion is in line with Snow (1993), who stated that people are equipped with self-forgiveness abilities. Individuals could realize their own mistakes as humans before giving forgiveness to people who hurt them. In other words, people will try to forgive themselves first before giving forgiveness to others. Meanwhile, mature age is also one factor that contributes to the forgiveness among the participants. This finding is supported by a recent study that revealed how people aged 45-72 years are more likely to give forgiveness (Younger, Piferi, Jobe, \& Lawler, 2004).

In terms of equality, the three participants experienced disappointment, sadness, and deep anger when they knew that their child got pregnant outside of marriage. Along the way, through the stages of forgiveness, their thoughts about their responsibilities as parents stimulated their guilt. In two participants, they tried to pray to God in this period. Praying is one of the factors that helped them through this experience. Specific beliefs and practices, including viewing an offender as spiritually similar or different of his/herself, responsibility/karma, blaming, restitution/apology, as well as practices such as meditation and prayer, may help to facilitate or act as barriers to forgiveness (Akhtar, Dolan, \& Barlow, 2017).

The three participants felt angry and betrayed by their daughter, but was finally able to forgive. Previous research found that commitment to forgive was mediated by cognitive interpretations of the betrayal incident (Finkel, Rusbult, Madoka, \& Hannon, 2002). This reaffirms that the experience of forgiveness is closely related to how to handle feelings of betrayal.

The empathize process in Worthington Jr.'s theory plays a significant role. All participants felt better in the empathize stage. For example, $\mathrm{R}$ felt more relaxed after empathizing with the events experienced by her daughter. Empathize stage also became a critical stage because it could change negative emotions into positive outcomes. Participants 
were able to proceed to the next stage after passing the empathize stage in giving forgiveness. This finding is in line with previous research that highlights how forgiveness can influence improvements in basic emotions such as sadness and anger by reducing negative emotions and increasing positive emotions (Worthington Jr, Witvliet, Pietrini, \& Miller, 2007). Experiences were found to be similar across the participants, whereby they experienced a tortuous process before finally generating positive emotions.

The strength of this study is the diversity of data obtained from the participants. All participants have different religions and beliefs. However, there does not appear to be a significant difference in efforts related to each respective religion. Additionally, the three participants came from different ethnicities. The variety of data regarding ethnicity and religion obtained shows that forgiveness can be universal. However, it would be interesting to conduct further research to explore forgiveness from various religious and belief reviews in Indonesia. Conversely, the limitation of this study is the small number of samples. Future studies should increase the number of samples to get a more representative result. In addition, further research may explore guilt and self-blaming of parents with the same problem of having children who experienced an unwanted pregnancy. Subsequent research is also possible to do research related with self-forgiveness to men as perpetrators of unwanted pregnancy.

\section{Conclusion}

Guilt, confusion, and fear of being subject to rumor in the extended family are major burdens among mothers of daughter who experienced unwanted pregnancy. The forgiveness process began with an active effort to carry out self-forgiveness, indicated by the emergence of efforts to empathize and think calmly about the problem at-hand. Next, mothers went through a phase of contemplation and assumed the failure of mothers in educating their daughter. During the forgiveness process, religious factor plays a significant role in providing the necessary means to calm down when dealing with the initial periods of discovering the unwanted pregnancy of their daughters.

\section{References}

Akhtar, S., Dolan, A., \& Barlow, J. (2017). Understanding the relationship between state forgiveness and psychological wellbeing: A qualitative study. Journal of Religion and Health, 56(2), 450-463. https://doi.org/10.1007/s10943-016-0188-9

Anand, E., Unisa, S., \& Singh, J. (2017). Intimate partner violence and unintended pregnancy among adolescent and young adult married women in South Asia. J. Biosoc, 49(2), 206-221. https://doi.org/10.1017/S0021932016000286

Bird, G., \& Melville, K. (1994). Families and intimate relationships. NY: McGraw-Hill.

Cichy, K.E., Lefkowitz, E.S., Davis E. M., \& Fingerman, K. L. (2013). You are such a disappointment!: Negative emotions and parents' perceptions of adult children's lack of success. $J$ Gerontol B Psychol Sci Soc Sci, 68(6), 893-901. https://doi.org/10.1093/geronb/gbt053

Coleman, P., K. (2006). Resolution of unwanted pregnancy during adolescence through abortion versus childbirth: Individual and family predictors and psychological consequences. J Youth Adolescence, 35(6), 903-911. https://doi.org/10.1007/s10964006-9094-X

Creswell, J. W. (2012). Educational research Planning, conducting, and evaluating quantitative and qualitative research (4th ed.). Boston: Pearson. - Google Search (4th ed.). Boston: Pearson. 
Enright, R. D., Freedman, S., \& Rique, J. (1998). The psychology of interpersonal forgiveness. In R. D. Enright, \& J. North (Eds.), Exploring Forgiveness. Madison, WI: University of Wisconsin Press.

Farber, N. B. (1991). The process of pregnancy resolution among adolescent mothers. Adolescence, 26(103), 697-716.

Fincham, F. D., Hall, J., \& Beach, S. R. H. (2006). Forgiveness in marriage: Current status and future directions. Family Relations, 55(4), 415-427. https://doi.org/10.1111/j.17413729.2005.callf.x-i1

Finkel, E. J., Rusbult, C. E., Madoka, K., \& Hannon, P. A. (2002). Dealing with betrayal in close relationships: Does commitment promote forgiveness? Journal of Personality and Social Psychology, 82(6), 956-974. https://doi.org/https://psycnet.apa.org/doi/10.1037/0022-3514.82.6.956

Ghaemmaghami, P., Allemand, M., \& Martin, M. (2011). Forgiveness in younger, middleaged and older adults: Age and gender matters. Journal of Adult Development, 18(4), 199-203.https://doi.org/10.1007/s10804-011-9127-x

Inazu, J. D. (2009). No future without (personal) forgiveness: Reexamining the role of forgiveness in transitional justice. Human Right Rev, 10(3), 309-326. https://doi.org/10.1007/s12142-009-0120-8

Mayun, K. A. W., Ani, L.S., \& Suariyani N., L., P. (2017). Causes of unwanted pregnancy among adolescents in Bali Province: a qualitative study. Public Health and Preventive Medicine Archive, 5(2), 114-119.

Miller, A.J., Everett, L., Worthington Jr., McDaniel, A. M. A. (2008). Gender and forgiveness: a meta-analytic review and research agenda. Journal of Social and Clinical Psychology, 27(8), 843-876. https://doi.org/10.1521/jscp.2008.27.8.843

Murray, R. J. (2002). Forgiveness as a therapeutic option. The Family. Journal: Counseling and Therapy for Couples and Families, 10(3), 315-321. https://doi.org/10.1177/10680702010003008

Nurrachman, N., \& Bachtiar, I. (2011). Psikologi perempuan: Pendekatan kontekstual Indonesia (Women psychology: Indonesian contextual approach). Jakarta: Universitas Atma Jaya.

Pareek, S., \& Mathur, N. (2013). Theoretical and Practical Vision on forgiveness: A Systematic Review of Ancient and Contemporary Literature. Indian Journal of Positive Psychology, 4(3), 434-442. https://doi.org/10.15614/IJPP/2013/V4I3/49872

Poerwandari, E. K. (2009). Pendekatan kualitatif untuk perilaku manusia (3rd ed.) (Qualitative approach of human behavior) (3rd ed). Depok: LPSP3 UI.

Romauli, S., \& Vindari, A. V. (2011). Kesehatan reproduksi (Reproductive health). Yogyakarta: Nuha Medika.

Rosmalinda. (2003). Teenage pregnancy. Retrieved October 1, 2019, from Inside Indonesia website: https://www.insideindonesia.org/teenage-pregnancy

Sarwono, S. W. (2001). Psikologi Remaja (ed 6.) (Psychology of adolescent). Jakarta: Raja Grafindo Persada.

Snow, N., E. (1993). Self-forgiveness. The Journal of Value Inquiry, 27(1), 75-80. https://doi.org/10.1007/BF01082713

Soetjiningsih. (2010). Bahan ajar: Tumbuh kembang remaja dan permasalahannya (Instructional materials: adolescent growth and development and its problems). Jakarta: Sagung Seto.

Sridawruang, C., Crozier, K., \& Pfeil, M. (2010). Attitudes of adolescents and parents towards premarital sex in rural Thailand: A qualitative exploration. Sexual and Reproductive

Healthcare,

l(4),

181-187. 
https://doi.org/https://doi.org/10.1016/j.srhc.2010.06.003

The Jakarta Post. (2015). Thousands of Indonesian women experience unwanted pregnancies. Retrieved October 1, 2019, from The Jakarta Post website: http://www.thejakartapost.com/news/2015/12/05/thousands-indonesian-womenexperience-unexpected-pregnancies.html

Toussaint, L. L., Worthington, E. L., \& Williams, D. R. (2015). Forgiveness and health: Scientific evidence and theories relating forgiveness to better health. Dordrecht: Springer. https://doi.org/10.1007/978-94-017-9993-5

Toussaint, Loren L., \& Jorgensen, K. M. (2008). Inter-parental conflict, parent-child relationship quality, and adjustment in christian adolescents: forgiveness as a mediating variable. Journal of Psychology and Christianity, 27(4), 337-346.

Utomo, I, D., \& Utomo, A. (2013). Adolescent pregnancy in Indonesia: a literature review. Retrieved from https://indonesia.unfpa.org/sites/default/files/pubpdf/Executive_Summary_WPD_201 3_\%28English\%29_0.pdf

Widyastuti. (2009). Kesehatan reproduksi (Reproductive health). Yogyakarta: Fitramaya.

Worthington Jr, E. L., Witvliet, C. V. O., Pieterini, P., \& Miller A, J. (2007). Forgiveness, Health, and Well-Being: A Review of Evidence for Emotional Versus Decisional Forgiveness, Dispositional Forgivingness, and Reduced Unforgiveness. Journal of Behavioral Medicine, 30(4), 291-302.

Worthington Jr, E. . (2006). Forgiving and reconciling: Bridges to wholeness and hope. DuPage County: InterVarsity Press.

Yin, R. K. (2009). Qualitative Research from Start to Finish. In Sage. https://doi.org/10.1111/j.1365-2648.2005.03456.x

Younger, J. W., Piferi, R. L., Jobe, R.L., \& Lawler, K. A. (2004). Dimensions of forgiveness: The views of laypersons. Journal of Social and Personal Relationships, 21(6), 837855. https://doi.org/DOI: 10.1177/0265407504047843 